\title{
Abundance as a conservation value
}

\author{
Kent H. Redford, Joel Berger and Steve Zack
}

European colonists described an abundance of spawning river herring Alosa pseudoharengus in north-eastern US coastal waterways 'in such multitudes as is almost incredible, pressing up such shallow waters as will scarce permit them to swime [sic]' (Wood [1634] 1977, in Hall et al., 2012).

A curious thing has happened to conservation biology. Many of us were inspired by our experiences with large groups of wild animals-be they in flocks, herds, or schools-and in many case drawn to conservation as a profession because of such experiences. And we have been increasingly educated through the work of historical ecologists on sliding baselines about how the abundance we encountered in our youth was nothing compared to the abundance of decades or centuries ago. Yet the discipline we embrace rarely considers abundance but instead has focused much of its attention and passion on loss, rarity, endangerment, minimum viable population sizes, and minimum viable conservation areas.

Lost in this focus on the rare and endangered is attention to that phenomenon that inspired many of us-abundance. Abundance of species was a part of the experience of Europeans in many of the lands they settled. Not only have we had ample experience with abundance but also with the speed at which it can be lost: the collapse of American chestnut Castanea dentata that went from one of the most abundant trees in the north-eastern USA to extinct in a matter of decades. Or the passenger pigeon Ectopistes migratorius and North American bison Bison bison both of which collapsed from populations of tens of millions to either extinct or a few hundred animals. More recently we have come to understand the nature of the collapse of once incredibly abundant marine species, from oysters to sea turtles to cod and river herring (Jackson et al., 2011).

These collapses are not just historical but have been occurring recently all around the world. The Madagascar radiated tortoise Astrochelys radiata was considered one of the world's most abundant tortoises and but is now almost extinct (Hudson, 2011). A similar pattern has been seen in recent collapses of once abundant Asian vultures, caribou,

Kent H. REDFORD Archipelago Consulting, Irvington NY 10533 USA. E-mail redfordkh@gmail.com

Joel Berger Department of Organismic Biology and Ecology, University of Montana, Missoula, Montana, USA

Steve Zack Wildlife Conservation Society, Portland, Oregon, USA forest elephants, sharks and the European horse chestnut Aesculapius hippocastanum. But despite evidence both from history and contemporary experience the conservation community has concentrated on species that are already endangered and has not seriously considered still abundant species to have a value for conservation.

When we refer to abundance we mean not just the overall number of individuals but also the diversity of individuals within a group. Evidence shows that there is a great deal of variation between individuals within large populations and that this variation can be of significant behavioural and ecological import (Hutchinson, 2008; Redford \& Feinsinger, 2001). Abundance is not only lots of the same but lots of differences as well.

We suggest there are four major reasons for conservationists to care about the phenomenon of abundance. Firstly, wildlife in abundance, sometimes referred to as wildlife spectacles, helps inspire us and builds connections with the natural world. Numerous travel agencies and media organizations advertise the chance to experience or see wildlife in abundance, be it flamingos, coral reef fish, bald eagles, monarch butterflies or wildebeest. Many of these scenes are the ones that inspire conservationists and their supporters.

Secondly, abundance is itself an ecological feature that maintains other species - including humans-and ecosystems (Gaston, 2011). Examples are numerous and reasonably well-documented, including forest elephants as seed dispersers, mound-building termites structuring communities, bees as pollinators, fish as sources of human food and conveyors of marine nutrients inland, and wolves indirectly as ecosystem engineers through trophic-level interactions.

Thirdly, and increasingly well understood, abundant species provide many vital ecosystem services on which nature and we rely. These include water filtration by oysters (Ermgassen et al., 2013), nutrient transport by salmon and river herring (Gende et al., 2002; Hall et al., 2012), nutrient cycling and herbivory by wildebeest (Holdo et al., 2006) and ocean mixing by a variety of organisms from krill to fish (Kerr, 2006).

Finally, it seems likely that it is easier in cost, and in management effort, to maintain abundance in wildlife populations than it is to keep once abundant and now rare species from extinction. Abundance is a buffer from perturbation whereas rarity is perpetual vulnerability.

In the face of these strong reasons why has abundance not become an explicit conservation value? Strong arguments have been made in a set of important papers by 
Gaston (2010, 2011) and Gaston \& Fuller (2007), presenting a set of arguments similar to ours for 'common' species. Yet, these papers have not achieved the influence they should. Instead, we in the conservation community continue with business as usual, illustrated by a recent paper by McCarthy et al. (2012), who measured achieving global biodiversity conservation targets as the conservation actions needed to achieve the minimum improvement in status necessary to reclassify ('downlist') each species to the next lowest category of extinction risk on the IUCN Red List. Rather than measuring our success as the decreased extinction risk of one category shouldn't we act to return large numbers of these species? We know this would cost more in the short term but should we ask for what we really want, or what we think will be supported?

We have created a global system, the IUCN Red List, which locks us into a focus on rarity and endangerment. This then informs the prioritization of those ecosystems (e.g. Hot Spots) or sites (e.g. Alliance for Zero Extinction sites) that contain these species. And all the while abundant species and the ecosystems containing them are becoming less abundant (Gaston, 2011; Lindenmayer et al., 2011). This is an approach that has been described as practising medicine only at the door of the emergency room of the hospital and wondering why the number of patients keeps growing.

We must broaden our focus on threatened species by also creating priority programmes to keep still abundant species abundant. Species such as the guanaco Lama guanicoe of southern South America, the Mongolian gazelle Procapra gutturosa, the white-eared kob Kobus kob lucotis of Southern Sudan, the migratory catfish of the Amazon, and the greater flamingo Phoenicopterus roseus. And we must expand the definition of 'recovery' so that success is not just demographic recovery but the recovery of abundance (Redford et al., 2011). Efforts directed at the American bison are a good example of this (Sanderson et al., 2008).

A good start in this direction was made at the Jeju World Conservation Congress, where IUCN decided to work on developing a Green List for species that will classify 'fully conserved' species-those that exist in ecologically significant numbers and interact fully with other species in their ecosystem. This begins the important process of broadening conservation away from a single focus on extinction and loss-an approach that may be an ineffective way to change public perception and engagement (Ladle \& Jenson, 2010)and adding abundance, a focus that will motivate and inspire the public towards conservation action.

\section{References}

Ermagassen, P.S.E., Spalding, M.D., Grizzle, R.E. \& GRUmbauCH, R.D. (2013) Quantifying the loss of a marine ecosystem service: filtration by the eastern oyster in US estuaries. Estuaries and Coasts, 36, 36-43.

Gaston, K.J. (2010) Valuing common species. Science, 327, 154-155. Gaston, K.J. (2011) Common ecology. BioScience, 61, 354-362.

Gaston, K.J. \& Fuller, R.A. (2007) Commonness, population depletion and conservation biology. Trends in Ecology and Evolution, 23, 14-19.

Gende, S.M., Edwards, R.T., Willson, M.F. \& Wipfli, M.S. (2002) Pacific salmon in aquatic and terrestrial ecosystems. BioScience, 52, 917-928.

Hall, C.J., JordaAn, A. \& Frisk, M.G. (2012) Centuries of anadromous forage fish loss: consequences for ecosystem connectivity and productivity. BioScience, 62, 723-731.

Holdo, R.M., Holt, R.D., Coughenour, M.B. \& Ritchie, M.E. (2006) Plant productivity and soil nitrogen as a function of grazing, migration and fire in an African savanna. Journal of Ecology, 95, 115-128.

Hudson, R. (2011) Madagascar's tortoises under siege.

Connect Magazine. March 2011, 18-21.

Hutchinson, W.F. (2008) The dangers of ignoring stock complexity in fishery management: the case of the North Sea cod.

Biology Letters, 4, 693-695.

Jackson, J.B.C., Alexander, K.E. \& Sala, E. (2011) (eds) Shifting Baselines. The Past and the Future of Ocean Fisheries. Island Press, Washington, DC, USA.

KERr, R.A. (2006) Creatures great and small are stirring the ocean. Science, 313,1717 .

LADLE, R.J. \& JEPSON, P. (2010) Origins, uses, and transformation of extinction rhetoric. Environment and Society: Advances in Research, 1, 96-115.

Lindenmayer, D.B., Wood, J.T., McBurney, L., MacGregor, C., Youngentob, K. \& BAnks, S.X. (2011) How to make a common species rare: a case against conservation complacency. Biological Conservation, 144, 1663-1672.

McCarthy, D.P., Donald, P.F., Scharlemann, J.P.W., Buchanan, G.M., Balmford, A., Green, J.M.H. et al. (2012) Financial costs of meeting global biodiversity conservation targets: current spending and unmet needs. Science, 338, 946-949.

Redford, K.H., Amato, G., Baillie, J., Beldonenico, P., Bennett, E.L. \& Clum, N. et al. (2011) What does it mean to successfully conserve a (vertebrate) species? BioScience, 61, 39-48.

Redford, K.H. \& Feinsinger, P. (2001) The half-empty forest: sustainable use and the ecology of interactions. In Conservation of Exploited Species (eds J.D. Reynolds, G.M. Mace, K.H. Redford \& J.G. Robinson) pp. 370-399. Cambridge University Press, Cambridge, UK.

Sanderson, E.W., Redford, K.H., Weber, B., Aune, K., Baldes, D., Berger, J. et al. (2008) The ecological future of the North American bison: conceiving long-term, large-scale conservation of wildlife. Conservation Biology, 22, 256-266.

Wood, W. (1977) New England's Prospect. Ed. A.T. Vaughan. University of Massachusetts Press, Amherst, USA. [originally published 1634]. 